\title{
Soil and sand contamination with canine intestinal parasite eggs as a risk factor for human health in public parks in Niš (Serbia)
}

\author{
M. RISTIĆ ${ }^{1}$, N. MILADINOVIĆ-TASIĆ ${ }^{2,3}$, S. DIMITRIJEVIĆ ${ }^{4}$, K. NENADOVIĆ $5,{ }^{*}$, D. BOGUNOVIĆ ${ }^{4}$, P. STEPANOVIĆ ${ }^{6}$, T. ILIĆ ${ }^{4}$
}

${ }^{1}$ Department of Animal Husbandry, University of Niš, Faculty of Agriculture, Kruševac, Kosančićeva 4, 37000 Kruševac, Serbia, E-mail: markoristicnis@yahoo.com; 2Department of Microbiology and Immunology, Faculty of Medicine, University of Niš, 18000 Niš, Serbia, E-mail: medfak@ni.ac.rs; ${ }^{3}$ Institute of Public Health of Niš, 18000 Niš, Serbia; ${ }^{4}$ Department for Parasitology, University of Belgrade, Faculty of Veterinary Medicine, Bul. Oslobodjenja 18, 11000 Beograd, Serbia,

E-mail: tamara@vet.bg.ac.rs, sanda@vet.bg.ac.rs; ${ }^{*}$ Department of Animal Hygiene, University of Belgrade, Faculty of Veterinary Medicine, Belgrade, Bul. Oslobodjenja 18, 11000 Beograd, Serbia, E-mail: katarinar@vet.bg.ac.rs; ${ }^{6}$ Department for equine, small animal, poultry and wild animal diseases, University of Belgrade, Faculty of Veterinary Medicine, Bul. Oslobodjenja 18,

11000 Beograd, Serbia, E-mail: pedja@vet.bg.ac.rs,prestepanovic@gmail.com

Article info

Received November 15, 2019 Accepted March 6, 2020

\section{Summary}

Regarding geographical distribution and clinical relevance, the most common canine geohelminths are Toxocara canis, ancylostomatids, and Trichuris vulpis. Canine intestinal parasites from the soil and sand present an important potential serious human health hazard, especially for the children preschool and school - age. This paper aimed to establish the degree of contamination of soil and sand with zoonotic parasites from the canine feces and the degree of risk they could pose for human health in public places and playgrounds in the city of Niš. Our parasitological study involved 200 soil samples and 50 sand samples from the public parks in the city of Niš in southeastern Serbia $\left(43^{\circ} 19^{\prime} 15^{\prime \prime} \mathrm{N}, 21^{\circ} 53^{\prime} 45^{\prime \prime} \mathrm{E}\right)$. From several locations, about $100 \mathrm{~g}$ of soil and sand was collected based on the bioclimatic indices. Parasitological diagnosis was performed using conventional qualitative and quantitative coprological methods, abiding by the recommendations about the diagnosis of parasitic diseases. In $38-46 \%$ of soil samples and $40 \%$ of sand samples seven species of endoparasites were diagnosed. In the samples of soil, a medium and high degree of contamination with the ascarid T.canis (14-22\%) was detected, as well as a low and medium degree of contamination with ancylostomatids ( $4-12 \%)$, and in the samples of sand, a variable degree of contamination with the helminths T. canis $(26 \%)$ and A. alata (16\%) was found. Astatistically significant difference was found in the contamination with $A$. alata eggs between the samples of sand and samples of soil. The studied public surfaces represent the reservoir of zoonotic parasites, which is a public health problem requiring a synergistic action of several factors to be successfully resolved, i.e. the implementation of prevention, surveillance, and control measures.

Keywords: intestinal parasites; dog; contamination; public spaces; public health

\section{Introduction}

More than 2 billion people worldwide are exposed to a risk for geohelminth infections. Regarding geographical distribution and clinical relevance, the most common canine helminths are Toxocara canis, Ancylostomatidae, and Trichuris vulpis, but the significance of these pathogens has been often underestimated by both veterinary and human medical professionals, as well as the general public (Traversa et al., 2014).

Human contact with the soil is one of the possible ways of spread-

\footnotetext{
* - corresponding author
} 
ing the canine intestinal parasites. These pathogens reach the soil via canine and human feces and can survive in this environment for a long period, making it a potential reservoir of infection (Tudor, 2015). The developing forms of geohelminths can survive the longest and enter the organism of susceptible individuals via skin or wounds in the visible mucosa (Ancylostoma caninum, Uncinaria stenocephala, Strongyloides stercoralis), causing a cutaneous larva migrans (Heukelbach \& Feldmeier, 2008; Jaleta et al., 2017), or by ingestion ( $T$. canis), when a visceral or ocular larva migrans is formed, which may persist in human tissues even for as long as several years (Aydenizöz-Özkayhana et al., 2008; Overgaauw \& van Knapen, 2013). The infections such as these are mainly sporadic, but in extraordinary situations (natural disasters and wars), they can also occur in epidemic scales (Tudor, 2015).

According to the information from the available literature, different degrees of soil contamination with helminth eggs and larvae from canine feces have been established. In Poland, the percentage was between $7.9 \%$ and $10.6 \%$ (Blaszkovska et al., 2012) and 18.6 \% (Bojar \& Kłapeć, 2012); in Italy, $24 \%$ (Habluetzel et al., 2003); in Portugal, 63.3 \% (Otero et al., 2014); in Slovakia, $79.2 \%$ (Rudohradska et al., 2011); in India, 12.84 \% (Sudhakar et al., 2013); in Spain, 71.33 \% (Martínez-Moreno et al., 2007); and in Romania, $22.22 \%$ (Tudor, 2015).

The studies performed in public parks in several Serbian cities, such as Belgrade (Pavlović et al., 2015), Požarevac, Kostolac (Pavlović et al., 2015) and Kruševac (Raičević \& Pavlović, 2019), have demonstrated a degree of contamination of urban green spaces, soil, and sand ponds in day-care facilities for pre-school children with zoonotic protozoa, nematodes, and cestodes.

This paper aimed to establish the degree of soil contamination and sand with zoonotic parasites from the canine feces and the degree of risk they could pose for human health in public places and playgrounds in the city of Niš.

\section{Material and Methods}

\section{Study design}

In the parasitologic examination performed in the period February - May 2019, we collected and analyzed 200 samples of soil and 50 samples of sand. The soil was sampled in three public parks in Niš: Tvrđava (Park 1) - 50 samples; Čair (Park 2) - 50 samples; Sveti Sava (Park 3) - 50 samples; and „Pet park" (Park 4) - 50 samples (representing a special, isolated group of sampled material), enclosed and situated within the Čair park. The sand was sampled only from the "free" part of Čair park (50 samples), since in other parks of interest for the study there were no sandpits.

\section{Study area}

The city of Niš $\left(43^{\circ} 19^{\prime} 15^{\prime \prime} \mathrm{N}, 21^{\circ} 53^{\prime} 45^{\prime \prime} \mathrm{E}\right)$ is the largest in southeastern Serbia and is the seat of the Nišava administrative district. It is situated at an altitude of $194 \mathrm{~m}$ and occupies an area of around $596.73 \mathrm{~km}^{2}$. According to the European NUTS (Nomenclature of territorial units for statistics) classification, it belongs to the NUTS3 category. Two important European transport corridors (Corridors $X$ and VII) directly or indirectly connect the city with the border European surroundings. The city has a moderate continental climate (warm summers and moderately cold winters), with an average yearly temperature of $12.08^{\circ} \mathrm{C}$, average precipitation of 577.79 $\mathrm{mm} / \mathrm{m}^{2}$ (the highest in October; the lowest in February), and average air humidity of $70.4 \%$ (the highest in January; the lowest in August) (source: Spatial plan of the Niš City Council).

The parks of interest for this study are situated in urban parts of the city, with a high population density and considerable fluctuation of pet and stray dogs. The Sveti Sava park is in one of the newer and largest communities in Niš, covering the area of 4.31 hectares. The Čair park is the largest in Niš situated in the city core, covering the area of 16.4 hectares. In 2016, an enclosed pet park was open within the Čair park, with the area of $5.000 \mathrm{~m}^{2}$, in which pet owners may walk or train their pets without leashes. The Tvrđava park is a complex cultural monument and an urbanistic hallmark of the central part of Niš. It is situated on the right bank of the Nišava river and occupies the area of 22.1 hectares.

\section{Samples}

From each of the above four locations, about $100 \mathrm{~g}$ of soil and $100 \mathrm{~g}$ of sand, for each sample was collected with a small shovel from the square area of $25 \times 25 \mathrm{~cm}$ and depth of $10 \mathrm{~cm}$. The material was collected from the sites without any vegetation (grass) to avoid more intense draining of a grass-covered soil. The sampling was performed based on the bioclimatic conditions indexes, abiding by the method of bioclimatogram by Uvarov (1931) and taking into account the parameters of average temperatures and humidity values for the studied area.

The number of soil and sand samples was determined by the location size and degree of apparent contamination with canine feces. The samples were packed in PVC bags and appropriately labeled (with date of sampling, location, number, and type of samples). After that, the samples were stored in a handheld refrigerator at $+4{ }^{\circ} \mathrm{C}$ and transported to the laboratory of the Department of Parasitology, Faculty of Veterinary Medicine, University of Belgrade. Parasitological diagnosis was performed in the first $24-48$ hours after the sample receipt.

\section{Parasitological examination}

The diagnosis of parasitic sample contamination was performed using the qualitative method without any concentration of parasitic elements - native examination by Pataki (Soulsby, 1986) and qualitative methods with the concentration of parasitic elements - the method of gravity flotation with saturated $\mathrm{NaCl}$ solution, specific weight 1,200 and saturated $\mathrm{ZnSO}_{4}$ solution, specific weight 1,400, at $20{ }^{\circ} \mathrm{C}$ (Urquhart et al., 1996), sedimentation method (Hansen and Perry, 1994), the method by Fülleborn (Euzeby, 1982), and sedimentation-flotation method for soil and sand (Pavlović, 2017). In all examined samples of soil/sand, using the method by McMas- 
ter (Kochanowski et al., 2013), we were able to diagnose fewer than 50 parasitic elements per $1 \mathrm{~g}$. That was the reason why the result of quantification was done using the qualitative FEC method (Pittman et al., 2010). Qualitative FEC defines the obtained results as "positive" or "negative". In the method of conventional gravity flotation the number of parasite eggs is valued as "minus“ (-) for negative findings, or "plus" (+) for positive findings (with three-level grading as ",,,+++++ "). The number of plus marks denotes the examiner's subjective opinion about the number of parasitic elements present beneath the two coverings of a microscopic specimen.

All the parasitological methods used in the study conform to the recommendations by the ISID (International Society for Infectious Diseases), OIE (World Organisation for Animal Health), WHO
(World Health Organization) and WAAVP (World Association for the Advancement of Veterinary Parasitology) related to the diagnosis of parasitic diseases.

\section{Statistics}

The data was processed with the GraphPad Prism statistics software. The study results were presented in tables. The statistical analysis of the data involved the application of descriptive tests and analytical non-parametric tests (the Chi-square test). The descriptive statistics were performed to report the data analysis that was presented as mean and standard deviations. The categorical variables were shown as frequencies and percentages. The statistical significance cut-off was set at $p<0.05$.

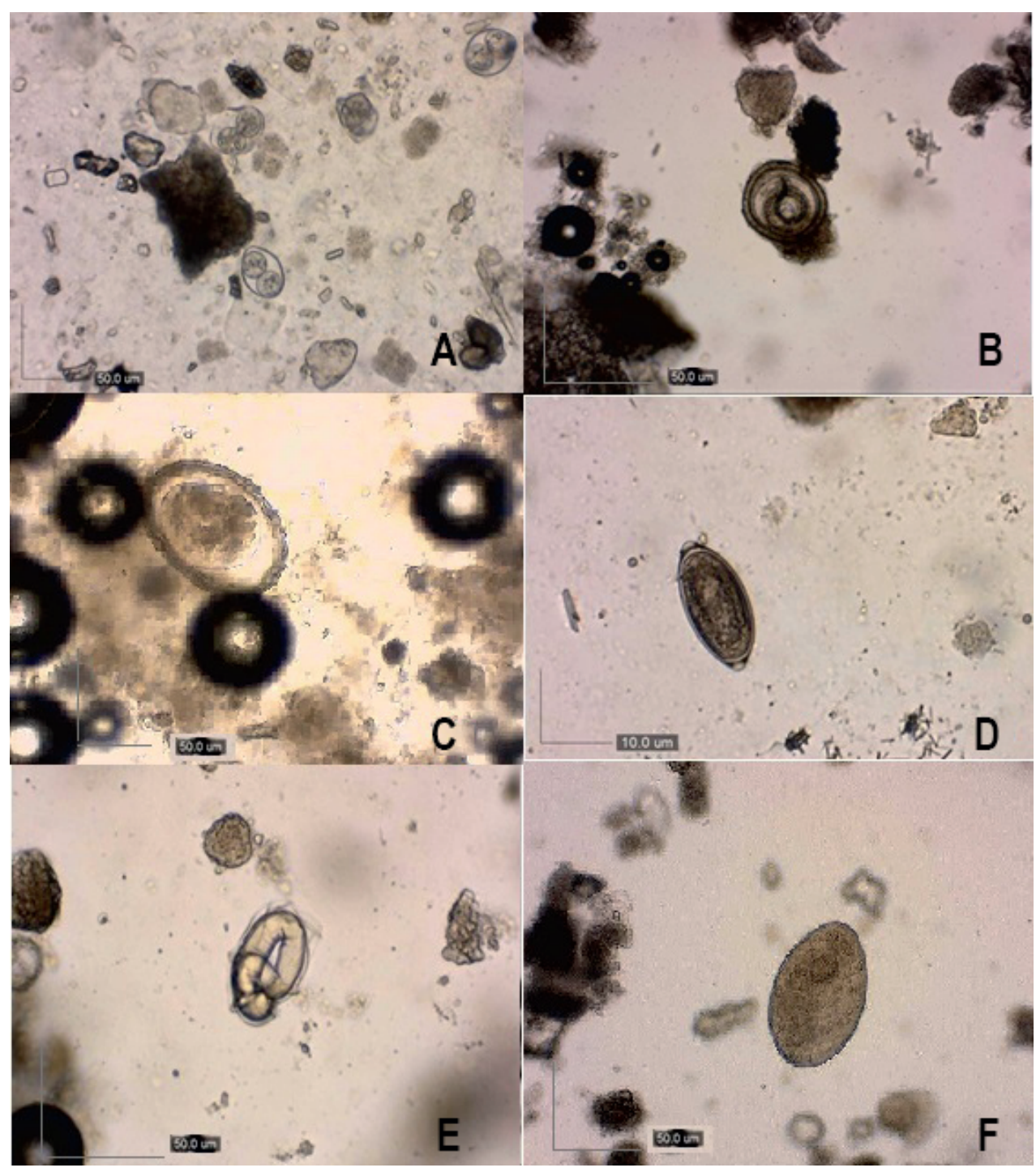

Figure 1. Parasitology diagnosis of soil samples. A) sporulated oocysts of Cystoisospora spp.; B) embryonated egg of T. canis (stage 1 larva); C) egg of T. leonina; D) egg of $T$. vulpis; E) embryonated egg of ancylostomatidae (stage 1 larva) (gravitation flotation method, $\mathrm{ZnSO}_{4}$ ); F) egg of $A$. alata, sedimentation method), 100x 
Table 1. Qualitative assessment of soil samples from the public parks in Niš - diagnosed endoparasites.

\begin{tabular}{|c|c|c|c|c|c|c|c|c|c|c|}
\hline \multirow{3}{*}{ ENDOPARASITE } & \multicolumn{8}{|c|}{ PARKS IN NIŠ (soil) } & \multirow{3}{*}{$x^{2}$} & \multirow{3}{*}{$P$} \\
\hline & \multicolumn{2}{|c|}{$\begin{array}{c}\text { Park } 1 \\
\mathrm{~N}=50\end{array}$} & \multicolumn{2}{|c|}{$\begin{array}{c}\text { Park } 2 \\
\mathrm{~N}=50\end{array}$} & \multicolumn{2}{|c|}{$\begin{array}{c}\text { Park } 3 \\
\mathrm{~N}=50\end{array}$} & \multicolumn{2}{|c|}{$\begin{array}{c}\text { Park } 4 \\
\mathrm{~N}=50\end{array}$} & & \\
\hline & $n$ & $\%$ & $n$ & $\%$ & $n$ & $\%$ & $n$ & $\%$ & & \\
\hline Cystoisospora spp. & 2 & 4 & 1 & 2 & 1 & 2 & 0 & 0 & 2.04 & 0.56 \\
\hline Toxocara canis & 9 & 18 & 8 & 16 & 11 & 22 & 7 & 14 & 1.21 & 0.75 \\
\hline Toxascaris leonina & 1 & 2 & 2 & 4 & 1 & 2 & 0 & 0 & 2.04 & 0.56 \\
\hline $\begin{array}{l}\text { Ancylostoma caninum/ } \\
\text { Uncinaria stenocephala }\end{array}$ & 4 & 8 & 5 & 10 & 6 & 12 & 2 & 4 & 2.25 & 0.52 \\
\hline Trichuris vulpis & 3 & 6 & 2 & 4 & 3 & 6 & 0 & 0 & 3.13 & 0.37 \\
\hline Alaria alata & 0 & 0 & 1 & 2 & 1 & 2 & 1 & 2 & 1.02 & 0.80 \\
\hline Total positive & 19 & 38 & 19 & 38 & 23 & 46 & 10 & 20 & & \\
\hline
\end{tabular}

\section{Ethical Approval and/or Informed Consent}

Not applicable.

\section{Results}

In the examined soil and sand samples, seven endoparasites were identified: protozoa from the Cystoisospora genus (Fig. 1A), nematodes (Toxocara canis - Fig. 1B, Toxascaris leonina - Fig. 1C, Trichuris vulpis - Fig. 1D, ancylostomatidae - Fig. 1E) and a trematode Alaria alata (Fig. 1F).
Each of the 4 methods of parasitological diagnostics applied was used according to the degree of sensitivity of the selected method for the appropriate type of parasite elements, as expected in the samples of the test material.

Results of qualitative examination of soil samples

Developing forms of endoparasites were found in $38 \%$ (19/50) soil samples from Park 1, 38 \% (19/50) samples from Park 2, $46 \%$ (23/50) samples from Park 3, and $20 \%$ (10/50) samples from Park 4 (Table 1).

Table 2. Qualitative assessment of soil samples from the public parks in Niš - diagnosed coinfections.

\begin{tabular}{|c|c|c|c|c|c|c|c|c|c|c|}
\hline \multirow{3}{*}{$\begin{array}{c}\text { MIXED } \\
\text { ENDOPARASITIC } \\
\text { CONTAMINATION }\end{array}$} & \multicolumn{8}{|c|}{ PARKS IN NIŠ (soil) } & \multirow{3}{*}{$x^{2}$} & \multirow{3}{*}{$P$} \\
\hline & \multicolumn{2}{|c|}{$\begin{array}{l}\text { Park 1 } \\
\mathrm{N}=50\end{array}$} & \multicolumn{2}{|c|}{$\begin{array}{c}\text { Park 2 } \\
\mathrm{N}=50\end{array}$} & \multicolumn{2}{|c|}{$\begin{array}{c}\text { Park } 3 \\
\mathrm{~N}=50\end{array}$} & \multicolumn{2}{|c|}{$\begin{array}{c}\text { Park } 4 \\
\mathrm{~N}=50\end{array}$} & & \\
\hline & $\mathrm{n}$ & $\%$ & $\mathrm{n}$ & $\%$ & $\mathrm{n}$ & $\%$ & $\mathrm{n}$ & $\%$ & & \\
\hline $\begin{array}{l}\text { Cystoisospora spp. } \\
\text { Toxocara canis }\end{array}$ & 1 & 2 & 0 & 0 & 1 & 2 & 0 & 0 & 2.02 & 0.57 \\
\hline $\begin{array}{c}\text { Toxocara canis } \\
\text { Toxascaris leonina }\end{array}$ & 1 & 2 & 0 & 0 & 1 & 2 & 0 & 0 & 2.02 & 0.57 \\
\hline $\begin{array}{l}\text { Toxocara canis } \\
\text { Ancylostomatidae }\end{array}$ & 1 & 2 & 3 & 6 & 2 & 4 & 1 & 2 & 1.63 & 0.65 \\
\hline $\begin{array}{l}\text { Toxocara canis } \\
\text { Trichuris vulpis }\end{array}$ & 0 & 0 & 0 & 0 & 1 & 2 & 0 & 0 & 3.05 & 0.39 \\
\hline $\begin{array}{l}\text { Toxascaris leonina } \\
\text { Trichuris vulpis }\end{array}$ & 0 & 0 & 1 & 2 & 0 & 0 & 0 & 0 & 3.05 & 0.39 \\
\hline $\begin{array}{l}\text { Toxocara canis } \\
\text { Alaria alata }\end{array}$ & 0 & 0 & 0 & 0 & 0 & 0 & 1 & 2 & 3.05 & 0.39 \\
\hline $\begin{array}{l}\text { Ancylostomatidae } \\
\text { Trichuris vulpis }\end{array}$ & 1 & 2 & 0 & 0 & 0 & 0 & 0 & 0 & 3.05 & 0.39 \\
\hline $\begin{array}{c}\text { Cystoisospora spp. } \\
\text { Toxocara canis } \\
\text { Trichuris vulpis } \\
\text { Toxocara canis }\end{array}$ & 0 & 0 & 1 & 2 & 0 & 0 & 0 & 0 & 3.05 & 0.39 \\
\hline $\begin{array}{c}\text { Ancylostomatidae } \\
\text { Trichuris vulpis }\end{array}$ & 1 & 2 & 0 & 0 & 0 & 0 & 0 & 0 & 3.05 & 0.39 \\
\hline Total positive & 5 & 10 & 5 & 10 & 5 & 10 & 2 & 4 & & \\
\hline
\end{tabular}




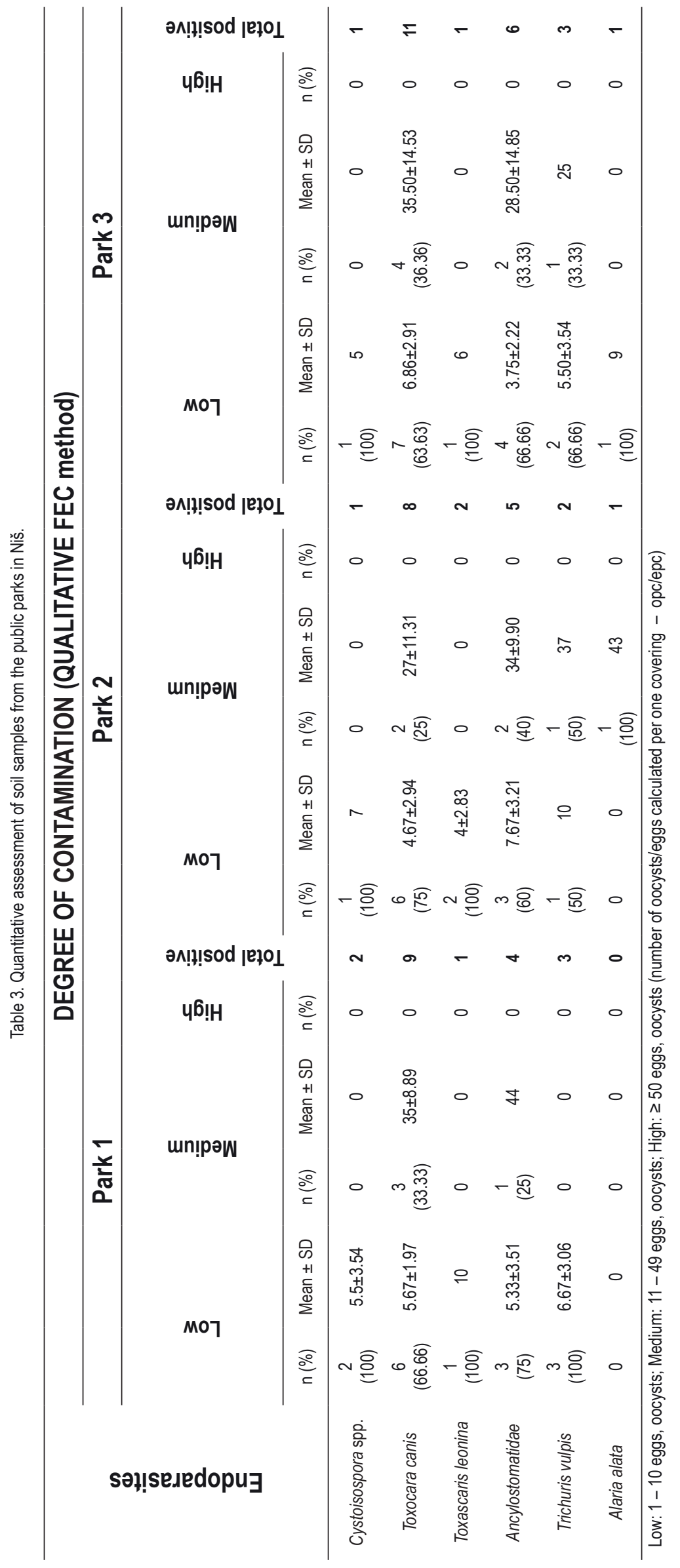


Table 4. Qualitative assessment of samples of sand in Park 2 - free space.

\begin{tabular}{|c|c|c|}
\hline \multirow{2}{*}{ ENDOPARASITES } & \multicolumn{2}{|c|}{ Sand samples $N=50$} \\
\hline & $n$ & $\%$ \\
\hline Cystoisospora spp. & 3 & 6 \\
\hline Toxocara canis & 13 & 26 \\
\hline Toxascaris leonina & 1 & 2 \\
\hline $\begin{array}{l}\text { Ancylostoma caninum/ } \\
\text { Uncinaria stenocephala }\end{array}$ & 4 & 8 \\
\hline Trichuris vulpis & 2 & 4 \\
\hline Alaria alata & 8 & 16 \\
\hline Total positive samples & 20 & 40 \\
\hline $\begin{array}{c}\text { MIXED } \\
\text { ENDOPARASITIC } \\
\text { CONTAMINATION }\end{array}$ & $\mathrm{n}$ & $\%$ \\
\hline $\begin{array}{l}\text { Cystoisospora spp. } \\
\text { Toxocara canis }\end{array}$ & 2 & 4 \\
\hline $\begin{array}{c}\text { Toxocara canis } \\
\text { Ancylostomatidae }\end{array}$ & 2 & 4 \\
\hline $\begin{array}{c}\text { Toxocara canis } \\
\text { Alaria alata }\end{array}$ & 3 & 6 \\
\hline $\begin{array}{c}\text { Ancylostomatidae } \\
\text { Alaria alata }\end{array}$ & 2 & 4 \\
\hline
\end{tabular}

$\mathrm{n}$ - number of positive samples; $\mathrm{N}$ - total number of samples

The most prevalent intestinal parasites were T. canis $(18 \%-9 / 50)$ and ancylostomatids $(8 \%-4 / 50)$ in Park $1, T$. canis $(16 \%-8 / 50)$ and ancylostomatids $(10 \%-5 / 50)$ in Park 2 , and T. canis $(22 \%-$ $11 / 50)$ and ancylostomatids $(12 \%-6 / 50)$ in Park 3 . The species from Cystoisospora genus were most prevalent in Park 1, with a prevalence rate of $4 \%(2 / 50)$, T. canis nematode, with a prevalence rate of $22 \%(11 / 50)$ was predominant in Park $3, T$. leonina, with a prevalence rate of $4 \%(2 / 50)$ in Park 2 , A. caninum/U. stenoce- phala with a prevalence rate of $12 \%(6 / 50)$ in Park 3 , and T. vulpis with a prevalence rate of $6 \%$ each $(3 / 50)$ in Parks 1 and 3 . The $A$. alata trematode was diagnosed in two soil samples, one from Park $2(2 \%-1 / 50)$ and one from Park $3(2 \%-1 / 50)$. In the examined soil samples we established the presence of eight mixed endoparasitic pathogens, and the most common was the double infection toxocariasis-ancylostomatidosis, with a prevalence of $6 \%(3 / 50)$ in Park 2, and 4 \% (2/50) in Park 3 (Tables 1 and 2). By analyzing

Table 5. Quantitative assessment of samples of sand in Park 2 - free space.

\begin{tabular}{|c|c|c|c|c|c|c|c|}
\hline \multirow{4}{*}{ Endoparasites } & \multicolumn{7}{|c|}{ DEGREE OF CONTAMINATION (QUALITATIVE FEC method) } \\
\hline & \multicolumn{7}{|c|}{ Park 2} \\
\hline & \multicolumn{2}{|c|}{ Low } & \multicolumn{2}{|c|}{ Medium } & \multicolumn{2}{|c|}{ High } & \multirow{2}{*}{$\begin{array}{c}\text { Total } \\
\text { positive }\end{array}$} \\
\hline & $\mathrm{n}(\%)$ & Mean \pm SD & $\mathrm{n}(\%)$ & Mean \pm SD & $\mathrm{n}(\%)$ & Mean \pm SD & \\
\hline Cystoisospora spp. & $3(100)$ & $6 \pm 2$ & 0 & 0 & 0 & 0 & 3 \\
\hline Toxocara canis & $8(61.54)$ & $4.75 \pm 2.31$ & $2(15.38)$ & $34 \pm 8.49$ & $3(23.07)$ & $77 \pm 24.56$ & 13 \\
\hline Toxascaris leonina & 0 & 0 & $1(100)$ & 36 & 0 & 0 & 1 \\
\hline Ancylostomatidae & $1(25)$ & 4 & $3(75)$ & $35.33 \pm 8.50$ & 0 & 0 & 4 \\
\hline Trichuris vulpis & $1(50)$ & 9 & $1(50)$ & 16 & 0 & 0 & 2 \\
\hline Alaria alata & $5(62.5)$ & $4.60 \pm 3.05$ & $3(37.5)$ & $20.67 \pm 10.97$ & 0 & 0 & 8 \\
\hline
\end{tabular}

Low: 1 - 10 eggs, oocysts; Medium: 11 - 49 eggs, oocysts; High: $\geq 50$ eggs, oocysts (number of oocysts/eggs calculated per a covering - opc/epc) 
Table 6. Comparison of the results obtained for soil and sand samples in the free space of Park 2.

\begin{tabular}{|c|c|c|c|c|c|}
\hline \multirow{3}{*}{ ENDOPARASITES } & \multicolumn{5}{|c|}{ PARK 2} \\
\hline & \multicolumn{2}{|c|}{$\begin{array}{c}\text { Soil } \\
N=50\end{array}$} & \multicolumn{2}{|c|}{$\begin{array}{l}\text { Sand } \\
N=50\end{array}$} & \multirow[t]{2}{*}{$P$} \\
\hline & $\mathrm{n}$ & $\%$ & $\mathrm{n}$ & $\%$ & \\
\hline Cystoisospora spp. & 1 & 2 & 3 & 6 & 0.62 \\
\hline Toxocara canis & 8 & 16 & 13 & 26 & 0.33 \\
\hline Toxascaris leonina & 2 & 4 & 1 & 2 & 1 \\
\hline $\begin{array}{l}\text { Ancylostoma caninum/ } \\
\text { Uncinaria stenocephala }\end{array}$ & 5 & 10 & 4 & 8 & 1 \\
\hline Trichuris vulpis & 2 & 4 & 2 & 4 & 1 \\
\hline Alaria alata & 1 & 2 & 8 & 16 & $0.04^{*}$ \\
\hline Total positive & 19 & 38 & 20 & 40 & \\
\hline
\end{tabular}

${ }^{*} p<0.05 ; n$ - number of positive samples; $N$ - total number of samples

the soil sampled from the "Pet Park", contamination with endoparasites was detected in $20 \%$ (10/50) of samples. Three types of endoparasites were diagnosed: T. canis nematode $14 \%(7 / 50)$, which was the most prevalent, ancylostomatids $4 \%(2 / 50)$, and $A$. alata trematode $2 \%$ (1/50) (Table 1).

\section{Results of quantitative examination of soil samples}

In the majority of soil samples, low levels of $T$. canis ascaridide contamination (66.66 \%; 5.67 1.97 epc in $\mathrm{P} 1,75 \% ; 4.67 \pm 2.94$ epc in P2 and $63.63 \% ; 6.86 \pm 2.91 \mathrm{epc}$ in P3) and ancylostomatids (75 \%; $5.33 \pm 3.51$ epc in P1, $60 \% ; 7.67 \pm 3.21 \mathrm{epc}$ in P2 and $66.66 \% ; 3.75 \pm 2.22 \mathrm{epc}$ ) were found in P3. Soil samples positive for the presence of $T$. leonina and Cystoisospora spp. showed low levels of contamination with this nematode in all three tested parks. A low degree of contamination of $T$. vulpis nematode (100\%; 6.67 \pm 3.06 epc in P1, $50 \%$; 10 epc in P2, $66.66 \%$; $5.50 \pm 3.54 \mathrm{epc}$ in $\mathrm{P} 3$ ) was diagnosed in all the parks tested. In one sample from Park 2 (50 \%; $37 \mathrm{epc}$ ) and Park 3 (33.33 \%; $25 \mathrm{epc}$ ), a moderate degree of contamination with $T$. vulpis was determined. An average degree of contamination by trematode $A$. alata in the sample originating in Park 2 and a low degree of contamination in the sample from Park 3 were determined (Table 3 ).

\section{Results of qualitative examination of sand samples}

In the examined sand samples collected from the free space in Park 2, we diagnosed the protozoa from the Cystoisospora genus $(6 \%-3 / 50)$, nematodes T. canis $-26 \%(13 / 50)$, T. leonina $2 \%(1 / 50)$, ancylostomatids $-8 \%(4 / 50)$, T. vulpis $-4 \%(2 / 50)$ and a trematode $A$. alata - $16 \%(8 / 50)$. The most common coinfection was toxocariasis-alariosis $(6 \%-3 / 50)$, while other mixed infections (Cystoisospora spp. - T. canis; T. canis - ancylostomatids and ancylostomatids $-A$. alata) were present in $4 \%(2 / 50)$ (Table 4).
Results of quantitative examination of sand samples

In most sand samples we detected a low degree of contamination with T. canis $(61,54 \% ; 4.75 \pm 2.31 \mathrm{epc})$, while in $23,07 \%(77 \pm 24.56$ epc) of positive samples a high degree of contamination with this ascarid was seen. We also established a medium degree of contamination with the species T. leonina (100\%; $36 \mathrm{epc}), T$. vulpis

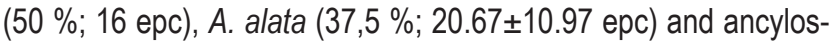
tomatids ( $75 \% ; 35.33 \pm 8.50 \mathrm{epc}$ ) (Table 5 ).

The analysis of soil samples from public city parks in Niš and Park 4 did not reveal any statistically significant difference $(p>0.05)$ (Tables 1 and 2). The analysis of soil and sand from the free space in Park 2, we found a significant difference $(p<0.05)$ in the prevalence of individual endoparasitic infection with the trematode $A$. alata, with a higher prevalence in sand samples - $16 \%(8 / 50)$ (Table 6).

\section{Discussion}

The study was performed in dry and humid periods in the spring season of 2019, investigating the prevalence of intestinal helminths eggs and protozoan oocysts in the samples of soil and sand from public parks and playgrounds for children in the city of Niš. The eggs of $T$. canis were diagnosed with the highest prevalence (16$22 \%$ in the soil; $26 \%$ in the sand), which agreed with other authors' findings, demonstrating the prevalence of this ascarid at $15.6 \%$ in the playgrounds in Turkey (Aydenizoz, 2006) and 15.5\% - 23.3\% in the playgrounds in Croatia (Stojčević et al., 2010). The literature data suggest that depending on the climate and geographical location, the level of contamination varies among different countries and within individual countries, where it is determined by the action of local geoclimatic factors. Accordingly, the contamination of public parks in Italy with eggs of $T$. canis was $63.6 \%$ (Giacometti 
et al., 2000), in Slovakia $61.3 \%$ (Rudohradská et al., 2011), in Serbia (Kruševac) $50.1 \%$ (Raičević \& Pavlović, 2019), while in Spain over $67 \%$ of parks and $1.24 \%$ of soil samples were contaminated (Ruiz et al., 2001).

The results of this study agree with the data about soil contamination with $T$. canis eggs obtained by the authors from the Czech Republic 5.0 to $20.4 \%$ (Dubná et al., 2007), Croatia - 15.5 do $23.3 \%$ (Stojčević et al., 2010), Spain - 16.4 \% (Dado et al., 2012), Poland - 16.6 \% (Bojar \& Káapeü, 2012), Romania - 17.17 \% (Tudor, 2015) and Greece - 17.2 \% (Papavasilopoulos et al., 2018).

The degree of contamination of sand samples with the ascarid $T$. canis, as was found in the study, is following the authors' findings from Slovakia - 6.8 to $27.0 \%$ (Ondriska et al., 2013), markedly higher than that from the Czech Republic - 11.9 \% (Dubná et al., 2007), Slovakia - 11.8 \% (Papajová et al., 2014) and slightly higher than the degree of contamination established in India - $17.64 \%$ (Sudhakar et al., 2013).

The contamination with ancylostomatids eggs was diagnosed in $8-12 \%$ of soil samples and $8 \%$ of sand samples, while the presence of $T$. vulpis eggs was established in $4-6 \%$ of soil samples and $4 \%$ of sand samples. The studies from Croatia report a higher degree of contamination of soil and sand samples from the playgrounds in Pula with T. vulpis eggs - $10-17.7$ \% (Stojčević et al., 2010).

A statistically significant difference in the degree of contamination with $A$. alata eggs was found between sand (16\%) and soil samples $(2 \%)$. In the samples of soil from Park 1, the eggs of this trematode were not found. The reason might have been a dry period of sampling (May) since a higher degree of contamination and a greater number of identified species are always reported in humid periods of the year (Nurdian, 2004). An increased number of soil samples positive for the presence of ascarids and ancylostomatids, as well as sand samples for the presence of $A$. alata, can be explained by favorable climatic conditions, with moderate temperatures, appropriate soil humidity and adequate environmental conditions in general. During the spring months, the eggs accumulated and concentrated in the soil, and due to low precipitation, they were not washed down to deeper layers of soil. The analysis of soil sections revealed that most of the eggs were situated at the depth of $0-4 \mathrm{~cm}$ (Storey \& Phillips, 1985). Since they are not situated on the surface, the eggs are probably protected from the action of direct sunlight and decay.

Such a long survival of ascarid eggs can be explained by the fact that these are most resilient helminth eggs, able to preserve their vitality for up to several years. On the other hand, protozoan cysts and oocysts have a reduced ability to survive in the natural environment (the cysts of Giardia spp. are less resilient than Cryptosporidium spp. 0ocysts). This fact may partly explain the absence of these protozoa in our study, in contrast to other authors' findings (Martínez-Moreno et al., 2007; Dado et al., 2012; Pavlović et al., 2015).

A difference was established in the number of positive soil (13) and sand samples (20). The sand was sampled only from the "free" part of Čair park (50 samples), since in other parks of interest for the study there were no sandpits.

Since the texture and humidity of samples have an impact on the length of survival of parasite eggs in the external environment, it should be emphasized that the samples of soil and sand in our study were almost identical as to their humidity. The reason is the vicinity of the Nišava river and its tributary Gabrovačka river, i.e. the fact that sand has an increased capacity to hold moisture. Nišava flows past the Parks 1 and 3 (from which exclusively soil was sampled), while the Park 2 is located further in the city core (the only park with free sand for sampling). In the Park 2, a higher degree of sand contamination ( $40 \%$ ) was found compared to soil contamination (38\%), which agreed with the results reported by Bojar and Kłapeć (2012), who detected the highest degree of contamination of sand (40\%) on the lake beaches in southeastern Poland. The authors stressed that in these places there was an increased chance for contamination of recreational areas with eggs of intestinal parasites from wild animals. The results are supported by the fact that in Poland and other European countries the phenomenon of synanthropization of wild animals, especially red foxes and feral pigs, has been observed, which opens new, additional opportunities for soil and sand pollution in public places in urban areas.

Most parasite eggs (especially embryonated ones) were found in the samples from shadowy places (under the trees or small shrubs). The reason is the ability of soil to hold humidity in such places and protection from direct sunlight, which significantly prolongs egg viability. The finding is also directly correlated with the behavior of dogs and their choice of spots for defecation (Rubel \& Wisniveskyy, 2005).

In our study, $5-20 \mathrm{~g}$ of soil and $5-20 \mathrm{~g}$ of sand were examined for each of these methods. The amount of sample tested was dependent on the method used. According to literature data from Mandarino-Pereira et al. (2010) tested soil samples (25g) using a modified centrifugal-flotation technique with $\mathrm{NaNO} 3$ (Dunsmore et al. 1984) and an adaptation of Rugai's et al. method (Carvalho et al., 2005) is a spontaneous sedimentation method. This method checks $100 \mathrm{~g}$ of soil and can be done the granulometric analyses of the samples were done and the soil classified into sand, silt, and clay according to their composition (Embrapa, 1997).

According to Kazacos (1983), the ability to diagnose parasitic elements in soil samples increases when a larger amount of soil $(30 \mathrm{~g})$ is used for analysis. These authors claim that $30 \mathrm{~g}$ of soil is the maximum amount of soil that can be effectively cultivated. In our study, the maximum amount of soil/sand sampled was $20 \mathrm{~g}$ for technical reasons. Our experience shows that a larger amount of the sample leads to the formation of a dense suspension with the formation of air bubbles, which make it difficult to microscopically examine the preparations and to diagnose parasitic elements.

The experience of other authors shows that sedimentation techniques are more practical and economical than flotation for soil 
and sand examination, but leave more impurity particles in the supernatant, which may interfere with the detection of the parasite by microscopy (Carvalho et al., 2005). Therefore, the flotation method with a saturated $\mathrm{ZnSO} 4$ solution is always recommended as an alternative. The flotation technique requires the use of a solution of appropriate specific gravity, which makes this technique more expensive than sedimentation (Dunsmore et al., 1984).

The diagnosed canine intestinal parasites from the soil and sand present an important potential serious human health hazard, especially for the children aged $3-5$ years. Supporting this notion are the diagnosed cases of parasitic zoonoses in Serbia (Gvozdenović et al., 2012; Mijatović et al., 2015; Miladinović Tasić et al., 2017; Perić et al., 2017), and that is the reason why a synchronized cooperation of professionals in the fields of both veterinary and human medicine is mandatory.

In conclusion, in the areas of public parks in the city of Niš, we established contamination with endoparasites of $38-46 \%$ of soil samples and $40 \%$ of sand samples. In the samples of soil, the contamination with $T$. canis ascarid (a low and medium degree) and ancylostomatids (a low and medium degree) was predominant, while in the samples of sand different degrees of contamination were present with $T$. canis and $A$. alata. Such a finding suggests a serious risk for human health since the above geohelminths are the etiological agents of visceral, ocular and cutaneous larva migrans syndrome, as well as of human larval alariosis. The finding of $A$. alata trematode in the samples of soil (2\%) and sand $(16 \%)$ indicates a significant circulation of stray dogs in the areas of public parks in the city of Niš. For owned dogs and people, they represent a reservoir of zoonotic parasites found in the soil and sand in the studied public spaces.

The resolution of this significant public health problem is therefore necessary through the Suggestion of measures, involving: a) control of parasite transmission in the environment, b) guidelines/information for dog owners for the prevention, maintenance of health, and spread of zoonotic diseases, and c) education of medical and veterinary professionals, pet owners and the general public.

\section{Conflict of Interest}

The authors declare that they have no competing interests.

\section{Acknowledgements}

This paper was realized in keeping with the projects No. TR31084, No. 173001 and No. TR30188 financed by the Ministry of Education and Science of the Republic of Serbia.

\section{References}

AydenIzöz, O.M. (2006): Soil contamination with ascarid eggs in playgrounds in Kirikkale, Turkey. J. Helminthol., 80: 15 - 18. DOI: 10.1079/joh2005311
AYdenIZÖZ, O.M., YAĞCI, B.B., ERAT, S. (2008): The investigation of Toxocara canis eggs in coats of different dog breeds as a potential transmission route in human toxocarosis. Vet. Parasitol., 152: 94 100. DOI: 10.1016/j.vetpar.2007.12.002

Blaszkowska, J., Wojcik, A., KuRnatowski, P., SzWabe, K. (2012): Geohelminth egg contamination of children's play areas in the city of Lodz (Poland). Vet. Parasitol., 192 (1-3): 228 - 233. DOI: 10.1016/j.vetpar.2012.09.033

BOJAR, H., KŁAPEĆ, T. (2012): Contamination of soil with eggs of geohelminths in recreational areas in the Lublin region of Poland. Ann. Agr. Env. Med., 19 (2): 267 - 270. PMID: 22742799

Carvalho, S.M.S., Gonçalves, F.A., Campos-Filho, P.C.C., GulMARÃES, E.M., CÁCERES, A.P.S.G., SouzA, Y.B., VIANNA, L.C. (2005): Adaptação do Métodode Rugai e colaboradores para análise de parasitas do solo [Adaptation of the Rugai et al. method for analysis of soil parasites]. Rev. Soc. Bras. Med. Trop., 38: 270 - 271. DOI: 10.1590/S0037-86822005000300015

Dado, D., Izquierdo, F., Vera, O., Montoya, A., Mateo, M., Fenoy, S., Galván, A.l., Garcia, S., Garcia, A., Aránguez, E., López, L., del Águlla, C., Miró. G. (2012): Detection of zoonotic intestinal parasites in public parks of Spain. Potential epidemiological role of microsporidia. Zoonoses Public Health, 59: 23 - 28. DOI: 10.1111/j.1863-2378.2011.01411.x.

Dubná, S., Langrová, I., Jankovská, I., Vadlejch, J., Pekár, S., NÁpraVNiK, J., FECHTnER, J. (2007): Contamination of soil with Toxocara eggs in urban (Prague) and rural areas in the Czech Republic. Vet. Parasitol., 144: 81 - 86. DOI: 10.1016/j.vetpar.2006.09.023

Dunsmore, J.D., Thompson, R.C.A., Bates, I.A. (1984): Prevalence and survival of Toxocara canis eggs in the urban environment of Perth, Australia. Vet. Parasitol., 16: 303 - 311

Embrapa, R.J. (1997): Centro Nacional de Pesquisa de solos. Manual de métodos deanálise de solo. Rio de Janeiro, $212 \mathrm{p}$.

EuzeBY, J. (1982): Experimental Diagnosis of Animal Helminthiases (Domestic Animals - Laboratory Animals - Primates). Practical Work in Veterinary Helminthology. Paris, France, Informations Techniques des Services Vétérinaires Ministère de l'Agriculture Publishing, Vol. 2, 364 pp.

Giacometti, A., Cirioni, O., Fortuna, M., Osimani, P., Antonicelli, L., Del Prete, M.S., Riva, A., Derdico, M.M., Petrelli, E., Scalise, G. (2000): Environmental and serological evidence for the presence of toxocariasis in urban area of Ancona, Italy. Eur. J. Epidemiol., 16: 1023 - 1026. DOI: 10.1023/a:1010853124085

Grozdenović, E., Mitrović, M., Dakić, Z., Stojković-ŠvirtLih, N., DuLović, O. (2012): Porodična epidemija kriptosporidijaze u Srbiji - prikaz slučaja. [Family Outbreak of Cryptosporidiosis in Serbia: Case Report]. Srp. Arh. Celok. Lek., 140 (9-10): 653 - 657. DOI: 10.2298/SARH1210653G

Habluetzel, A., Traldi, G., Riggierl, S., Attlli, A.R., Scuppa, P., Marchetti, R., MenGhinl, G., Esposito. F. (2003): An estimation of Toxocara canis prevalence in dogs, environmental egg contamination and risk of human infection in the Marche region of Italy. Vet. Parasitol., 113: 243 - 252. DOI: 10.1016/s0304-4017(03)00082-7 
Hansen, J., Perry, B. (1994): The epidemiology, diagnosis and control of helminth parasites of ruminants. A Hand Book. 2nd ed. Nairobi, Kenya, ILRAD Publishing, 129 pp.

Heukelbach, J., Feldmeier, H. (2008): Epidemiological and clinical characteristics of hookworm-related cutaneous larva migrans. Lancet Infect. Dis., 8 (5): 302 - 309. DOI: 10.1016/S14733099(08)70098-7

KazACOS, K.R. (1983): Improved methods for recovering Ascarid and other helminthes eggs from soil associated with epizootics and during survey. Am. J. Vet. Res., 44: 896 - 900

Kochanowski, M., Dabrowska, J., Karamon, J., Cencek, T., Osiński, Z. (2013): Analysis of the accuracy and precision of the McMaster method in detection of the eggs of Toxocara and Trichuris species (Nematoda) in dog faeces. Folia Parasitol., 60 (3): 264 - 272. DOI: 10.14411/fp.2013.030

Mandarino-Pereira, A., Silva de Souzab, F., Lopesc, C.W.G., PerelRA, M.J.S. (2010): Prevalence of parasites in soil and dog feces according to diagnostic tests. Vet. Parasitol., 170: 176 - 181. DOI: 10.1016/j.vetpar.2010.02.007

Martínez-Moreno, F.J., Hernández, S., López-Cobos, E., Becerra, C., Acosta, I., Martinez-Moreno, A. (2007): Estimation of canine intestinal parasites in Córdoba (Spain) and their risk to public health. Vet. Parasitol., 143 (1): 7 - 13. DOI: 10.1016/j.vetpar.2006.08.004 Mijatović, D., Ćalasan, N., Simin, V., Lalošević, D. (2015): Nadzor pacijenta sa toksokarijazom - Prikaz slučaja. [Disease monitoring in toxocariasis - A case report]. MD-Medical Data, 7: 327 - 329. COBISS.SR-ID 220655116

Miladinović Tasić, N., Đordević, N., Zdravković, D., Tasić, A. (2017): Prevalence of giardiasis in asymptomatic individuals in the territory of the city of Niš. Acta Med. Median., 56: 48 - 54. DOI:10.5633/ amm.2017.0308

NuRDIAN, Y. (2004): Soil contamination by parasite eggs in two urban villages of Jember. J IImu Dasar, 5: 50 - 54

Ondriska, F., Mačuhová, K., Melicherová, J., Reiterová, K., VAlentová, D., Beladičová, V., Halgoš, J. (2013): Toxocariasis in urban environment of western Slovakia. Helminthologia, 50: 261 - 268. DOI: 10.2478/s11687-013-0139-x

Otero, D., Niusse, R., Gomes, L., Alho, A., Overgaauw, P., Hoek, D., Madeira de Carvalho, L.M. (2014): Prevalência de ovos de Toxocara spp., no solo de parques publicos da area da Grande Lisboa, Portugal - resultados preliminares. (In Portuguese) [Prevalence of Toxocara spp. eggs in public parks soil of Greater Lisbon, Portugal - Preliminary results]. Acta Parasitol. Port., 20 (1/2): 47 - 50

Overgaauw, P.A., van Knapen, F. (2013): Veterinary and public health aspects of Toxocara spp. Vet. Parasitol., 193 (4): 398 - 403. DOI: 10.1016/j.vetpar.2012.12.035

Papajová, I., PipIKová, J., PApaj, J., ČIžmár, A. (2014): Parasitic contamination of urban and rural environments in the Slovak Republic: dog's excrements as a source. Helminthologia, 51 (4): $273-280$. DOI: 10.2478/s11687-014-0241-8

Papavasilopoulos, V., Pitiriga, V., Birbas, K., Elefsiniotis, J., Bonatsos, G., TsakrIs, A. (2018): Soil contamination by Toxocara canis and human seroprevalence in the Attica region, Greece. Germs, 8 (3): 155 - 161. DOI: $10.18683 /$ germs.2018.1143

Pavlović, I., Teodor, B., Stojanović, D. (2003): Rezultati parazitološkog pregleda parkova i bazenčića za pesak u vrtićima Požarevca i Kostolca [Results of parasitological examination of parks and sand boxes in kindergartens Pozarevac and Kostolac]. Zbornik radova Stručnog skupa „Kontrola štetnih organizama u urbanoj sredini", VI Beogradska Konferencija sa međunarodnim učešćem, Beograd, Srbija, 2003, 159 - 163

Pavlović, I., Jovičić, D., Vegara. M., llić, Ž., Radosaviluević, V. (2015): Uticaj klimatskih promena na biodiverzitet parazita kontaminenata zelenih površina u Beogradu [Impact of climate change on biodiversity of green space contamination parasites in Belgrade]. Ecol., 22 (79): 450 - 455

PavLović, I. (2017): Methods of examination of soil and sand to presence of parasites eggs. Affiliation: The Intellectual Property Office of Republic of Serbia, Certificate 999 No. 2770/2017A0098/2017, May 2017. DOI: 10.13140/RG.2.2.33676.31368

Pittman, S.J., Shepherd, G., Thacker, J.B., Myers, H.G. (2010): Modified technique for collecting and processing fecal material for diagnosing intestinal parasites in swine. J. Swine Health Prod., 18 (5): $249-252$

Perić, J., Lekić, B., ReluÍ́, V., ĆIRKović, L., ŠKILJeVIć, D. (2017): Cutaneous Larva Migrans - Report of 2 new cases locally acquired in Serbia. Serbian J. Dermatol. Venerol., 9: 145 - 153. DOI: 10.1515/ sjdv-2017-0016

RaIČEvIĆ, J., PAvlović, I. (2019): Rezultati parazitoloških pregleda parkova u Kruševcu tokom 2017. godine. [Results of parasitological examinations of parks in Krusevac during 2017]. Zbornik kratkih sadržaja 24. Godišnjeg Savjetovanja doktora veterinarske medicine Republike Srpske (Bosna i Hercegovina), Jun 12 - 15, 2019, Bijeljina, Republika Srpska, 83 - 84

RUBEL, D., Wisnivesky, C. (2005): Magnitude and distribution of canine fecal contamination and helminth eggs in two areas of different urban structure, Greater Buenos Aires, Argentina. Vet. Parasitol., 133, 339 - 347. DOI: 10.1016/j.vetpar.2005.06.002

Rudohradská, P., Papajová, I., JuRIš, P. (2011): Pets as a source of parasitic soil contamination in the settlements of marginal ised groups of inhabitants. Folia Vet., 55 (Suppl. 1): $33-35$

Ruiz, D.M.R., GariJo, M.M., Alonso, F.D. (2001): Prevalence and viability of eggs Toxocara spp. and Toxascaris leonina in public parks in eastern Spain. J. Helminthol., 75: 169 - 173. PMID: 11520442

SouLSBY, E.J.L. (1986): Helminthes, arthropods and protozoa of domesticated animals. 7th ed., London, UK, Bailliere Tindall Publishing, $809 \mathrm{pp}$.

StoJČEVIĆ, D., Sušić, V., LUČINGER, S. (2010): Contamination of soil and sand with parasites elements as a risk factor for human health in public parks and playgrounds in Pula, Croatia. Vet Arhiv, 80 (6): 733 - 742. ISSN: 0372-5480

StoreY, G.W., PHILLIPS, R.A. (1985): The survival of parasite eggs throughout the soil profile. Parasitol., 91: 585 - 590. DOI: 10.1017/ 
s003118200006282x

Sudhakar, N.R, Samanta, S., Sahu, S., Raina, O.K., Gupta, S.C., MadHu, D.N., Kumar, A. (2013): Prevalence of Toxocara species eggs in soil samples of public health importance in and around Bareilly, Uttar Pradesh, India. Vet. World, 6 (2): 87 - 90. DOI: 10.5455/vetworld.2013.87-90

Traversa, D., Frangipane di Regalbono, A., Di Cesare, A., La Torre, F., Drake, J., Pietrobelli, M. (2014): Environmental contamination by canine geohelminths. Parasit. Vectors, 7: 67. DOI: 10.1186/1756-3305-7-67
TUDOR, P. (2015): Soil contamination with canine intestinal parasites eggs in the parks and shelter dogs from Bucharest area. Agric. Agricult. Sci. Proc., 6: 387 - 391. DOI: 10.1016/j.aaspro.2015.08.103 URQuHART, G., AREMOUR, J., DunChAn, J.L., Dunn, A.M., JeninIs, F.W. (1996): Veterinary Parasitology. 2nd ed. The University of Glasgow, Oxford, UK, Blackwell Sciences Publishing, 307 pp.

Uvarov, B.P. (1931): Wetter und klima in ihren beziehungen zu den insecten [Weather und Climate in their Relation to Insects]. J. Appl. Entomol., 17 (1): 156 - 177. DOI: 10.1111/j.1439-0418.1931. tb00167.x 